\title{
Monetary Policy, Fiscal Policy, and Confidence
}

\author{
John Silvia, Chief Economist \\ Wells Fargo Securities, LLC, One Wachovia Center, 301 South College Street, NC0602 \\ Charlotte, NC 28288-0602, USA \\ Tel: 704-374-703 Fax: 704-383-3102 E-mail: john.silvia@wellsfargo.com
}

Azhar Iqbal (Corresponding Author)

Vice President and Econometrician

Wells Fargo Securities, LLC, One Wachovia Center, 301 South College Street, NC0602

Charlotte, NC 28288-0602, USA

Tel: 704-383-6805 Fax: 704-383-3102Ｅ-mail: azhar.iqbal@wellsfargo.com

Received: December 3, $2010 \quad$ Accepted: July 5, $2011 \quad$ doi:10.5539/ijef.v3n4p22

\begin{abstract}
The relative effectiveness of monetary and fiscal policies is an on-going debate among macroeconomists. Our study is the first to examine the effect of monetary and fiscal policies on confidence. We provide a theoretical framework which highlights the role of confidence in business cycles as well as the effect of monetary and fiscal policies on confidence. Moreover, we discuss how monetary and fiscal policies restore confidence, which helps to lead to economic recovery from recessions/slowdowns. Furthermore, we test the effect of monetary and fiscal policies on confidence as well as on the real GDP.

Our results suggest that monetary and fiscal policies have a stable, long-run (as well as short-run) relationship with confidence and real GDP. Moreover, real GDP and confidence move together in both the long-run as well as in the short-run.
\end{abstract}

Keywords: Monetary Policy, Fiscal Policy, Confidence, GDP

JEL Classification: C32; E32; H30.

\section{Introduction}

The relative effectiveness of monetary and fiscal policies is an on-going debate among macroeconomists. Our study is the first to examine the effect of monetary and fiscal policies on confidence (both investors and consumers). Confidence plays a vital role in business cycles. We provide a theoretical framework which highlights the role of confidence in business cycles as well as effect of monetary and fiscal policies on confidence. Moreover, we discuss how monetary and fiscal policies restore confidence, which helps to lead to economic recovery from recessions/slowdowns. Furthermore, we test the effects of monetary and fiscal policies on confidence as well as on the aggregate economic activities (real GDP).

The recent (2007-09) U.S. financial crisis/recession was caused by the housing sector. The National Bureau of Economic Research (NBER) announced (on December 1, 2008) Q4 2007 as beginning of the recession. The U.S. policymakers, however, responded to the crisis much earlier than the announcement. For instance, Federal Reserve Board (the Fed) reduced the Federal Funds target rate (fed funds rate) in September 2007 to 4.75\% from 5.25\% (50 basic points). In addition, the Bush administration passed a $\$ 120$ billion tax stimulus package and the package was distributed in the first half of 2008. There are number of factors which made 2008 a very difficult year for the economy and financial sector. For instance, first, the oil price shock (oil price was above $\$ 100$ between March 2008 and September 2008) and then collapse of Bear Stearns, Lehman Brothers and American International Group (AIG) fueled the financial crisis. Particularly, Lehman's bankruptcy (September 2008) blow up the global financial system. Moreover, by the end of the 2008 the U.S.' financial crisis became the global financial crisis (also known as the global financial meltdown). The consequences of the global financial meltdown are; interest rates cut by the central banks and trillions of dollars announce in fiscal stimulus packages by the governments around the world. In the United States, the Fed eased monetary policy and reduced fed funds rate to a record low, 0 to $0.25 \%$ ranges by December 2008. In addition, the Fed bought trillions of dollars worth of securities. On the other hand, President Obama signed (February 2009) a \$787 billion “American Recovery and Reinvestment Act of 2009” (ARRA 2009). 
In sum, the Fed and the Obama administration worked aggressively to restore the U.S economy and financial system. The joint effect by the Fed (monetary policy) and the Obama administration (fiscal policy) brought in positive real GDP growth rates for $3^{\text {rd }}(2.2 \%)$ and $4^{\text {th }}(5.6 \%)$ quarters of 2009 . Moreover, the stock market (S\&P 500) was up (more than 28\%) for 2009.

There is a long on-going debate about the role/effectiveness of monetary policy and fiscal policy. In simple words, whether monetary policy and fiscal policy are useful during recessions. There are two answers to the question. One group of economists believes monetary policy is the sole answer e.g. Taylor (2009), Mishkin (2009) and many more. This group favors monetary policy as a powerful tool for countercyclical stabilization. In addition, they believe fiscal policy doesn't work during the recessions (Taylor 2009) and may cause inflation, crowding out as well as inefficient use of resouces. On the other hand, a group of economists, including winner of the 2008 Nobel Prize, Paul Krugman, believe fiscal policy is a right answer. Furthermore, they criticize monetary policy and argue that the policy has serious limitations. The limitations of monetary policy include the liquidity trap, zero-bound interest rate, inflation and easy monetary policy creates asset bubbles.

Both groups criticize each other and have solid arguments and rationales in support of their views. But in reality, especially, during the recent recession and financial crisis, countries including USA, UK, EU, Japan, Canada, China and many more, followed both policies (monetary and fiscal) simultaneously. That being said, central banks cut the key interest rates and increase money supply. At the same time, governments around the world offered trillions of dollars in fiscal stimulus. Therefore, we have three views; first, monetary policy is good. Second, fiscal policy is better. Finally, in reality, countries followed both policies simultaneously. That raises the questions; first, whether monetary policy is better than fiscal policy, or vice versa? Second, whether both are good or bad? Finally, whether a combination of both policies is a better option than an individual one?

In literature, typically, researchers analyzed the effects of monetary and/or fiscal policy on overall economic activity (real GDP growth rate for instance) or on aggregate consumption (Taylor 2009). Our study is the first to evaluate the effects of monetary and fiscal policies on confidence. Confidence (both investors and consumers) plays a key role in business cycles. As Akerlof and Shiller (2009) mentioned in their famous book that human psychology drives financial events worldwide, i.e., a blind faith in ever-rising home prices to plummeting confidence in capital markets. (Note 1) Simply put, human psychology plays an important role in business cycles e.g., over confidence as well as high ambitions( or may be gluttony) bring in boom and bust and then policymakers step in and restore confidence through monetary and fiscal policies that accompanied recovery. Therefore, confidence is a very important factor in the business cycles, especially, a dream of a solid recovery is incomplete without a confidence. That being said, if investors are confident then they will invest and create supply of goods and services as well as employment. On the other hand, if consumers are hopeful about the future (their earning wouldn't smash) then they will spend (especially discretionary spending) and personal spending is the major component of the GDP. In real world examples, when the U.S. House did not pass the (\$ 700 billion) fiscal stimulus bill on September 29, 2008, that day the S\&P 500 index dropped more than $8 \%$ and October 2008 was the worse month for the S\&P 500 index since the great Depression. The S\&P 500 index dropped more than $20 \%$ ( month-over-month (MoM) percent change) in October 2008, highest MoM percent drop since April 1932. On the other hand, when President Obama signed the bill in February 2009 that restores confidence; for example the S\&P 500 index gained more than $22 \%$ during March-June 2009. That was a perfect example of fiscal policy's effect on confidence (see next section for more detail). Another example, on January 22, 2008, the Fed announced a 75 basic points (bps) cut in the key interest rate (fed funds rate) in a surprise announcement (announcement came in before the opening bell of the U.S.'stock markets) in order to support the U.S. financial markets. One major reason of this action was that stocks fell around the world on Monday January 21, 2008 and U.S.' markets were close on that day due to a public holiday (Martin Luther King Jr. day). Moreover, the Fed reduced fed funds rate by 125 bps (from 4.25\% to 3.00\%) between December 2007 and January 2008. The immediate effect of the rate cut was a less volatility in the U.S. stocks markets. That was a perfect example of monetary policy's effects on confidence (see next section for more detail).

Our study provides a theoretical framework which explains how confidence brings in boom-bust as well as recession-recovery. Furthermore, how monetary and fiscal policies effects (restore) confidence, which helps to lead to an economic recovery. In addition, we evaluate, empirically, the effect of monetary and fiscal policies on the aggregate economic activity (real GDP) as well as on confidence. We use month-to-month change in the S\&P 500 index as a proxy for confidence. (Note 2) We conduct an econometric analysis using two types of data, (1) a monthly data set and (2) a quarterly. In case of monthly data set, we test the effects of monetary and fiscal policies on confidence. Analysis based on quarterly data shows the relationship among the policies, confidence and real GDP. We also examine association between confidence and real GDP. 
We follow a comprehensive econometric approach that is we first test the order of integration for all time series. We employ a complete unit root methodology and use traditional unit root tests (introduced by Dickey-Fuller, Phillips-Perron, and Kwiatkowski-Phillips-Schmidt-Shin) and efficient unit root tests (introduced by Elliot-Rothenberg-Stock and Ng-Perron). (Note 3) Then we examine the relationship among monetary/ fiscal policy, confidence and real GDP using cointegration (Johansen) test. We also test the short-run relationship among the variables using vector error correction model (VECM).

Our results suggest that monetary and fiscal policies have a stable, long-run (as well as short-run) relationship with confidence and real GDP. Moreover, real GDP and confidence move together in both the long-run and the short-run. Furthermore, based on our analysis, we suggest that both policies are important to restore confidence. That being said, during recessions a combination of both policies is necessary to restore confidence, which helps to lead to an economic recovery.

The rest of the paper is organized as follows. Section 2 discusses the theoretical framework for confidence, monetary, and fiscal policies. The econometric set-up is described in Section 3. Section 4 provides the information about the data set. In section 5 we discuss the empirical results. The concluding remarks are gathered in Section 6.

\section{Monetary Policy, Fiscal Policy, and Confidence: A Theoretical Framework}

We provide a theoretical framework which explains how confidence brings in recession-recovery as well as boom-bust. The economic world segregates between monetarist (follower of monetary policy) and fiscalist (believer of fiscal policy). Both groups have solid justifications and arguments for their favorite policy and criticism on the other e.g. monetarists (fiscalists) have justifications for monetary (fiscal) policy and criticism on fiscal (monetary) policy. But, especially during the recent financial crisis and recession, we have seen a combination of both policies was implemented by countries around the world. That raises the question of the relative effectiveness of monetary and fiscal policies i.e.; which policy is better than other? Or a combination of both policies is better than an individual one? The traditional way to examine the relative effectiveness of the policies is to test the effects of monetary and fiscal policies on overall economic activity (real GDP growth rate, for example). Our study is the first (best of our knowledge), in the way; we not only test the effects of monetary and fiscal policies on the real GDP but also on confidence. The following section of the study discusses the importance of confidence and effects of monetary and fiscal policies on confidence.

\subsection{Importance of Confidence: A Rational Rationale}

As Akerlof and Shiller (2009, p.72) suggested that the drop in the confidence was so fundamental during the great Depression and that stay for a decade. Moreover, confidence (so that the economy) restore after World-War-II (WWII). This indicates that a recovery without confidence is highly unlikely. That raises the important questions; (1) why confidence is important? (2) How monetary and fiscal policies restore confidence? The answer to the first question is discussed here and section 2.2 and 2.3 will explain the answer to the second question.

In our view, two factors play a key role in the decision-making-process of economic agents (investors, lenders, consumers for instance), which are (i) ability and (ii) willingness. Furthermore, ability is a quantitative factor, which consists of monetary aggregation (income, financial assets, loans, etc) and willingness is a qualitative factor including expectations about economy, earning, future ability, etc. For instance, in case of a lender (financial institutions including banks and bank holding companies), two things are very important in a lending decision; (1) ability to lend and (2) willingness to lend. Where ability to lend indicates how much liquidity/reserve is available (a quantitative factor) for lending. On the other hand, willingness to lend includes expectation about economy, financial sector, borrowers' reputation and expected future ability to lend, etc. A lender will lend/under-write a loan when she is able to and willing to lend (lending-decision = willingness + ability). In our view, both willingness and ability are important factors in decision-making-process. The willingness factor, however, is more important, contains more weight. For example, as willingness factor includes expected ability to lend and thereby a lender may be lend/under-write more (more than her ability to lend) in recovery phase and that happened because she is expecting a higher future ability (of course, expecting higher future returns and a better economy). Therefore, lenders start lending more, more than their ability to lend, and that may bring in a lending boom. On the other hand, in contraction/slowdown (after boom) willingness reduce (confidence lost) and she may be lend less (lesser than her ability). That happened because she is expecting a diminishing future ability to lend (along-with reduce earning and uncertainty about economy) and that bring in a bust or may freeze the credit market. In a real world example, during the recent financial crisis, lenders refused to lend and credit market froze. It is true that lenders' ability to lend reduced; due to huge losses and many of them filed for bankruptcy, but there were many lenders, which still have ability to lend. There was, however, no willingness to lend. Particularly, Lehman Brothers' bankruptcy was a major cause which smashed lenders' willingness to lend. For instance, TED spread jumped to $3.4 \%$ by October 2008 
(highest since July 1981). As we know, TED spread (difference between the interest rates on interbank loans and short-term U.S. government debt) is an indicator of perceived risk in the general economy. A widening in the TED spread indicates that lenders believe the risk of default on interbank loan (also known as counter party risk) is increased. Therefore, during the financial crisis, the willingness factor hit harder than the ability factor. Another example, in the U.S., banks' willingness to make consumer loans dropped to $-47 \%$ during the recent financial crisis (lowest level of willingness since $2^{\text {nd }}$ quarter 1980). Therefore, we believe that willingness factor (confidence) plays a vital role in credit/lending boom-bust.

This two factor approach is also important in investors' decision-making-process. For instance, investors make investment-decision based on their ability to and willingness to invest. Moreover, ability includes monetary resources (equity, loans, etc) and willingness is a qualitative factor including expected returns from investment, expectation about the economy, expected ability to invest, etc. An investor, usually, invest when he is able to and willing to invest. Again, factors, ability and willingness, are important but willingness is more important. For example, since willingness factor includes expected ability to invest thereby an investor may invest more (more than his ability to invest) in recovery phase and that occurs, because, he is expecting a higher future ability to invest (also expecting higher future returns and a better economy). Again, higher investment, higher than the ability to invest, may leads to an investment boom. On the other hand, in contraction (or after boom) willingness reduce (confidence lost) and that may cause reduction in investment (lesser investment than his ability to invest). That happened, because, he is expecting a diminishing future ability to invest (along-with reduce earnings and uncertainty about the economy) and that bring in bust or recession. The process can also be repeated for consumers in their decision-making-process and that is consumers' spending decision (especially discretionary spending) based on ability to and willingness to spend. Therefore, willingness is an important factor in decision-making-process and that also causes fluctuation in business cycles. During recessions (and economic slowdown/bust), we believe that willingness (we call it confidence) factor disappear from the economy and monetary and fiscal polices are important tools in order to restore confidence. Moreover, during the bust or recession, policy makers (monetary and fiscal policies) step in and restore confidence (repair willingness + ability factors), which leads to a recovery. In the next section of the study we discuss how monetary and fiscal policies restore confidence.

\subsection{Monetary Policy and Confidence}

We first discuss monetary policy as a countercyclical stabilization tool and then its effect on confidence. In case of the U.S., the main objective of the monetary policy, in the Fed's view, is that "The Federal Reserve sets the nation's monetary policy to promote the objectives of maximum employment, stable prices, and moderate long-term interest rates" (The Federal Reserve Board). The conventional monetary policy's tools are interest rate and money supply. The Federal Open Market Committee (FOMC) decides the short term interest rate which is known as the Federal funds target rate ( popularly known as fed funds rate). The Fed controls money supply through Open Market Operation. (Note 4) The limitations of monetary policy include the liquidity trap, zero-bound lower interest rate and inflation. Another criticism is that the Fed failed to prevent asset bubbles/the great Depression.

Keynes introduced the liquidity-trap notion and according to Krugman (2009) "[D]efinition of a liquidity trap is, purely and simply, a situation in which conventional monetary policy-open-market purchases of short-term government debt— has lost effectiveness." The zero-bound lower interest rate implies that nominal interest rate can not be lower than zero (can not be negative). Put differently, at zero-lower-bound nominal interest rate borrowers will pay no interest rate and nominal interest rate would not be in negative territory because at negative interest rate lenders prefer not to lend. In case of liquidity trap, when central bank increases money supply people increases their holding (hold more money). A famous real world example of liquidity trap/zero-bound-lower interest rate is the Japan's lost decade (1990s is known as a lost decade for the Japan). During the 1990s, the Bank of Japan brought down nominal interest rate to zero and increased money supply but both tools failed to stimulate the Japanese economy. Moreover, during the recent financial crisis and recession (2007-09), the Fed reduced the fed funds rate to $0-0.25 \%$ range since December 2008. Furthermore, the Fed increased money supply (both real and nominal M2) by more than $8 \%$ in 2008. Due to record low interest rate (0-025\%) and a rapid growth in money supply many economists including Krugman (2009) are suggesting that the U.S. is in a liquidity trap. But we rephrase the question; is there a liquidity trap? If yes then does it bad? In our view, term liquidity-gap is more suitable, especially for the recent U.S. financial crisis/ recession, instead of liquidity-trap. By liquidity-gap we mean a situation in which demand for liquidity is higher than supply of liquidity. In other words, monetary policy is still effective (hasn't lost effectiveness at least) but demand for liquidity/money increases rapidly, at a faster rate than supply of liquidity. In addition, liquidity-gap is not good because it represents a confidence lost.

During the recent financial crisis; investors, lenders, borrowers (especially private sector) demand for money (more liquid assets) increased rapidly. Due to Lehman Brothers' bankruptcy and collapse of the AIG there was a 
confidence lost. One example of lost confidence is that the S\&P 500 index dropped more than $20 \%$ (MoM percent change) in October 2008. The important factors which blow confidence up were including Lehman's bankruptcy, collapse of the AIG and the U.S. house did not pass ( $\$ 700$ billion) fiscal stimulus bill (although they alter their decision later). Due to these factors credit market froze, lenders stopped lending and thereby demand for cash/liquidity skyrockets. The Fed reduced short term interest rate (fed funds rate) to a record low, $0-0.25 \%$ range by December 2008; 175-200 bps cut during September-December 2008 time period. Moreover, the Fed increased money supply (nominal M2) by more than $4 \%$ during the same time period. In addition, the Fed pumped liquidity in the financial system through non-conventional methods (TAF, TALF, and TSLF, for instance). (Note 5) Due to these extraordinary steps, took by the Fed, the liquidity-gap begin narrowing and credit market start unfreezing by middle of 2009. The liquidity-gap starts narrowing because of the following factors; (1) the Fed increases liquidity supply at a faster rate, (2) When the Fed starts acting aggressively it restore the confidence and lender (private sector) begin lending and investors start investing, and (3) as the confidence start restoring demand for liquidity (growth rate of liquidity demand) start decreasing. Therefore, liquidity-gap widen due to confidence lost and reduce/narrower when confidence restore. Furthermore, in our view, monetary policy is effective and helps to narrower the liquidity-gap and restores confidence.

A famous criticism on monetary policy is that easy monetary policy may create inflation. As changes in the stock of money only affect nominal variables e.g. prices, wages, etc (also known as "Money Neutrality"). But many economists including Blanchard have said that there is no real evidence of existence of the money neutrality and it very much a matter of faith. In our view, whether money supply cause inflation or not is depends on aggregate growth (real GDP growth rate) and aggregate demand. In real world example, in case of the Japan's lost decade, easy monetary policy didn't create inflation. In fact, easy monetary policy and (a kind of) deflation were seen together in the Japan during 1990s. In case of the recent U.S. recession/financial crisis, in spite of an easy monetary policy, prices are still (by July, 2010) at the Fed's comfortable level. This happened because aggregate growth rate (real GDP growth rate) is still below its potential level. Moreover, in spite of a below trend real GDP growth rate, liquidity demand increased during the recent financial crisis/recession and it happened due to confidence lost and thereby we did not see a rapid rise in general price level.

Another criticism on the Fed/monetary policy is that it failed to prevent asset bubbles. In particular, the Fed failed to prevent the great Depression (1929-33) and housing bubble of 2000s, which lead to the great recession (2007-09). In our view, it is a debatable issue. For instance, the Fed was created in 1913 and in 1929 (beginning of the great Depression) it was just a teenager (sixteen/seventeen year old) and it is not a rational argument that the Fed(a teenager that time) failed to prevent the great Depression. There are many causes of the great Depression including lost of the confidence. Akerlof and Shiller (2009) suggested that confidence lost was a major cause of the great Depression and confidence restored after WWII; real economic recovery began once confidence restore. Furthermore, one can argue that the U.S. economy did not see another great Depression (at least till 2007) since WW-II. A group of economists including Taylor (2009) criticized that the Fed kept interest rate (fed funds rate) very low, below 2\% between December 2001 and October 2004 (35 months) and that low interest rate fueled the housing bubble of 2000s. Bernanke (2010) defended the Fed's policy during the 2002-04 period and said that due to 2001 recession, terrorist attack, and uncertainty there was a risk of deflation and thereby the Fed kept short term interest rate very low for an extended period of time. In our view, due to several factors including Information Technology (IT) boom-bust, Enron scandal, 9/11 terrorist attack, 2001 recession is associated with a jobless recovery, etc, there were huge uncertainty and lack of confidence. The Fed used its tools to restore confidence and stimulate the economy. Therefore, easy monetary policy (during 2002-04) helped to restore confidence and stimulates the economy.

In sum, monetary policy is an effective and a useful tool to combat recessions and financial crises. Moreover, due to recessions, financial crises, and exogenous shocks (oil prices spike, 9/11 terrorist attack, etc) economic agents (investors and consumers in particular) lost their confidence. The Fed step in and use his conventional (interest rate and money supply) and non-conventional tools (TAF, TALF, and TSLF for instance) to restore confidence, which helps to lead to an economic recovery.

\subsection{Fiscal Policy and Confidence}

Fiscal policy normally works through incentives (tax reduction/break, increase unemployment insurance benefits or duration, for instance) and spending (federal, state and local government spending). Keynes emphasizes on fiscal policy and suggested that during recessions public spending is an important tool to stimulate the economy and 
increase aggregate demand. He also introduced the multiplier notion — net addition in the output may be higher than the increment in public spending.

A group of economists including Milton Friedman, J.B. Taylor and many more, however, criticize fiscal policy. The common criticisms on fiscal policy include the crowding out, inflation and higher future tax rates. Moreover, Taylor (2009) argued that the 2008 tax stimulus did not work. But in our view, fiscal policy is an important tool to restore confidence during recessions and economic slowdown, which helps to lead to an economic recovery.

To some extent, fiscal policy changes automatically during expansion and recession. It is also known as automatic-stabilizers. In simple words, automatic-stabilizers work without explicit policy action by government. For instance, the size of the government budget deficit tends to increase as a country enters recession. That is because of the following factors; more people lost their jobs and file for unemployment insurances, increase insurance benefits payments. Income tax is generally, at least, somewhat progressive. If a person's income rises, then his/her average tax rate increases. This implies that as incomes fall, households pay less as a proportion of their income in direct taxation. Same is true for corporate tax that is generally based on profits, rather than turnover. In a recession profits tend to fall much faster than turnover. Therefore, a corporation pays much less tax while having only slightly less economic activity. In booms, usually less people lost their jobs and thereby less insurance benefits payments by the government. Moreover, people and corporate income/ profits rises so that the tax revenue. Automatic-stabilizers are very important tools, however, it only affect the ability factor of consumers and investors. For instance, if a person lost his job then his ability and willingness to spend affects that is due to disruption in income and uncertainty about future income. Automatic-stabilizer may restore his ability to spend (at least some part of the lost income he will get, trough unemployment benefits, for a specific time period) but may not restore willingness to spend. It is also common during the recessions, especially, during the recent financial crisis and recession, that people have risk/fear of layoff (they may lose their job). In this case ability factor may not be affect but confidence (willingness) lost would be there. That being said, automatic-stabilizers may not restore confidence and we need explicit fiscal stimulus packages.

In recent (2007-09) recession, the U.S. federal government introduced many incentives including, 2008 tax stimulus package, increased unemployment insurance benefits duration, first time home buyer tax credit and the most interesting one "cash for clunkers". In our view, due to these incentives personal spending did not fall much (nominal personal spending fall, mom basis, only nine times between December 2007 and December 2009) and without these incentives personal consumption could have fall much more. A group of economists including Taylor (2009) argued that 2008 tax stimulus didn't work. Moreover, they claimed that personal consumption did not raise much, did not show much positive effects. In addition, Taylor (2009) suggested that fiscal spending couldn't work during the great Depression as well as in case of the Japan's lost decade. In our view, during the recent recession, there were number of factors which could decrease personal consumption much more than people even imagine. For instance, huge wealth loss (due to asset prices' fall and stock market crash), job loss (recent recession has the highest job loss, over eight million, since WW-II), fear of layoff/ job loss, credit market froze (credit wasn't easy available to consumers even they qualified for that), etc, destroyed consumers ability plus willingness to spend. Reduction in consumption, however, was not that much and it happened because of fiscal (of course monetary) policy. The U.S. government worked very aggressively (the Bush and Obama administration introduced many stimulus packages). The stimulus packages boost confidence and repair ability factor. Moreover, fiscal stimulus shows federal government's comments to stimulate the economy and increase positive expectations about future economy, which leads to increase willingness to spend (and invest).

The answer to the question whether fiscal policy worked during the great Depression (as well as during the Japan's lost decade) is a debatable issue. Romer (2009), however, provided a very precise answer that is fiscal policy did not try properly during the great Depression. For example, by 1933 there was a balanced-budget norm. The Roosevelt administration increased public spending in 1934(and the great Depression ended in 1933) but the spending was fairly small (the deficit rose by $1.5 \%$ of the GDP in 1934). Moreover, due to balanced-budget requirements, States and local government were forced to cut spending and raised tax rates because economic activities and state tax revenue were falling (this happened in recent recession too and many States including New York, California, North Carolina, to name a few, reduced their spending due to huge budget deficits). Therefore, fiscal policy did not try properly during the great Depression. It supports our thesis that is there was a confidence lost and fiscal policy did not try appropriately and if fiscal policy were implemented properly then confidence could had restored, which helped to lead to economic recovery, without delay. In case of the Japan's lost decade, Japanese's government did not follow a bold fiscal policy because they increased fiscal spending in early 1990s (1992-94) but that spending; (a) too-little, too-late and (b) raised tax rates (increased consumption tax rate in 1997) in order to reduce the deficit (see 
Yellen, 2009 for more detail). Therefore, during the great Depression and the Japan's lost decade, fiscal policy did not implement properly.

It is not necessary that fiscal deficit will be reduced by increasing future tax rates. Fiscal deficit can be reduced by cutting spending (discretionary spending) and automatic-stabilizers will also help to reduce deficit (as we explained earlier). Another criticism on fiscal policy is known as crowding-out. (Note 6) But in our view, due to recession investors hesitate to invest (lack of confidence). They may be still able to invest but willingness factor disappear and to bring back the willingness (confidence) government announce fiscal stimulus packages (incentives plus spending). In recent recession, we have seen that fiscal policy didn't crowding out in fact there's crowding-in (Krugman 2009).

In the recent recession U.S. government followed some non-conventional fiscal policy tools including the Troubled Asset Relief Program (TARP). (Note 7) Since financial sector was the epicenter of the recent recession and economic recovery without a financial sector recovery seems unrealistic. Therefore, U.S. Treasury and the Fed worked together (combination of monetary and fiscal policies) and helped to restored lenders, investors and consumers confidence (in general, overall confidence) which leaded to the economic and financial sector recovery. For instance, the S\&P 500 was up more than $28 \%$ for 2009 and real GDP growth rates for $3^{\text {rd }}$ and $4^{\text {th }}$ quarters of 2009 were $2.2 \%$ and $5.6 \%$, respectively.

\section{Econometric Set-up}

\subsection{Unit Root Testing: Introduction}

Dickey and Fuller $(1979,1981)$ introduced the idea of a unit root and proposed a standard unit root testing procedure which is known as ADF (Augmented Dickey-Fuller) test of unit root. But unit root testing became popular in economics, especially among macro-economists, after the publication of the seminal paper by Nelson and Plosser (1982). Nelson and Plosser employed unit root methodology on 14 U.S. macroeconomic time series and they could reject the null hypothesis of a unit root for only one time series, which was the unemployment rate. In addition, Nelson- Plosser concluded that many macroeconomic series are non-stationary. That implies many macroeconomic series exhibit trending behavior or a non-stationary mean. There are many other unit root tests, other than ADF test, available in the literature. For instance; Phillips-Perron (1988) (PP), and Kwiatkowski-Phillips-Schmidt-Shin (1992) (KPSS) tests of unit root (also known as traditional unit root tests); tests introduced by Elliot-Rothenberg-Stock (1996) (ERS) and Ng-Perron (2001) (also known as efficient unit root tests). We employ all these tests on the data series. (Note 8)

\subsection{The Cointegration and Vector Error Correction Model}

Nelson-Plosser (1982) findings that many macro time series may contain a unit root has spurred the development of the theory of non-stationary time series analysis. Engle and Granger (1987) pointed out that a linear combination of two or more non-stationary series may be stationary. If such a stationary linear combination exists, the non-stationary time series are said to be cointegrated. The stationary linear combination is called the cointegrating equation and may be interpreted as a long-run equilibrium relationship among the variables. The purpose of the cointegration test is to determine whether groups of non-stationary series are cointegrated or not. We implements VAR-based cointegration tests using the methodology developed in Johansen $(1988,1995 \mathrm{a})$.

Consider a VAR;

$$
y_{t}=A_{1} y_{t-1}+\ldots \ldots .+A_{p} y_{t-p}+B x_{t}+\varepsilon_{t}
$$

Where $y_{\mathrm{t}}$ is a k-vector of non-stationary, I(1), variables, $x_{\mathrm{t}}$ is a $d$-vector of deterministic variables, and $\varepsilon_{t}$ is a vector of innovations. We may rewrite this VAR;

Where

$$
\Delta y_{t}=\Pi y_{t-1}+\sum_{i=1}^{p-1} \Gamma_{i} \Delta y_{t-i}+B x_{t}+\varepsilon_{t}
$$

$$
\Pi=\sum_{i=1}^{p} A_{i}-I, \quad \Gamma=-\sum_{j=i+1}^{p} A j
$$

The Granger's representation theorem states that if the coefficient matrix $\Pi$ has reduced rank $r(\mathrm{r}<k)$ then there exist $k \times r$ matrices $\alpha$ and $\beta$ each with rank $r$ such that $\Pi=\alpha \beta^{\prime}$ and $\beta^{\prime} y_{t}$ is I (0). $r$ is the number of cointegrating relations (the cointegrating rank) and each column of $\beta$ is the cointegrating vector (See Johansen, 1995 for more detail). 
A vector error correction model (VECM) is a restricted VAR designed to use with non-stationary series that are known to be cointegrated. The VECM has cointegration relations built into the specification so that it restricts the long-run behavior of the endogenous variables to converge to their cointegrating relationships while allowing for short-run adjustment dynamics. The cointegration term is known as the error correction term since the deviation from long-run equilibrium is corrected gradually through a series of partial short-run adjustments (See Johansen, 1995 for more detail). Therefore, cointegration test's results will reveal the long-run relationship properties, whether or not there is a long-run relationship exists. The VECM results will indicate the short-run relationship.

\section{The Data}

We use two types of data set in this study, which are a monthly and quarterly. Our empirical analysis covers 1959-2009 time spans for both data sets, because mostly data series goes back to that date. Keynes (1936, chapter 12) mentioned that consumers and investors' sentiments (he referred as "animal spirits") might influence the real economy. Many economists, since then, have examined the relationship between confidence and real GDP (between confidence and personal consumption). Mostly, economists used consumer confidence indices (Reuters/ University of Michigan and the Conference Board indices) as a proxy for confidence (see Ludvigson, 2004 and Akerlof and Shiller, 2009 for a survey). But consumer confidence indices only cover the consumers' sentiments and the missing elements are investors and lenders' sentiments. On the other hand, the stocks market (the S\&P 500 index) is a much broader measure of a confidence. For example, consumers, investors, lenders and even policymakers are related to the market either directly (own stocks, 401(k), pension, etc) or indirectly (employers are related to the stock market). Moreover, major economic agents (consumers, investors, lenders and policy-makes) pay attention to daily performance of the stock market. The stock market (S\&P 500 Index) is a single best indicator, which shows not only the current state of the economy (as well as confidence) but also expectations about future. Generally speaking, when the S\&P 500 index is moving upward then the people are expecting a better present and future economy (basically they are confident). On the other hand, if the S\&P 500 index is going down/ or volatile (moving up and down quickly) then there is an uncertainty/ confidence lost. In addition, we can see a real time effect of a policy changes or a shock on confidence through the S\&P 500 index. For example, on September 15, 2008 Lehman Brothers filed bankruptcy and the S\&P 500 index dropped more than $4 \%$ on that day. Another example, on September 29, 2008 the U.S. House did not pass stimulus bill and on that day the S\&P 500 index plunged more than $8 \%$. Therefore, we believe the S\&P 500 index is a better measure of confidence.

We use month-over-month (MoM) change in the S\&P 500 index as a proxy for confidence. (Note 9) There are several benefits of using MoM change in the S\&P 500 index (we call it a confidence series) as a proxy for confidence. For example, a continuously negative pattern of confidence series shows confidence lost and a series of positive values indicate confidence restore. A volatility (or a higher growth rate) of the confidence series is not desirable because it reflects booms (from $+v e$ to $+v e$ ) and bust (from -ve to $-v e$ ) and uncertainty (from +ve to -ve and $-\mathrm{ve}$ to $+\mathrm{ve}$ ). Therefore, confidence series may reveal whether economy is in boom or bust and economic agents are confident or not. We use short-term interest rate (fed funds rate) and money supply (M2, nominal and real) as proxy for monetary policy. We use net Federal government budget saving as a proxy for fiscal policy. Congressional Budget Office (CBO) estimates a cyclically adjusted net Federal government budget saving, which accounts for automatic-stabilizers and thereby we also use that series as a proxy for fiscal policy. We use real GDP as a proxy for aggregate economic activity.

We test the relationship between confidence and monetary/ fiscal policies using monthly data set. We also examine the effects of monetary/ fiscal polices and confidence on the real GDP using quarterly data, because real GDP only available quarterly. The data sources are IHS Global Insights and CBO. (Note 10)

\section{Empirical Results}

We start with a simple correlation analysis. We use original series for correlation analysis, did not perform any function on the series, e.g., $\log$ or difference, etc, see Table 1 for results. Correlation analysis reveals whether the series of interest have a statistically significant correlation coefficient with each other or not. Interestingly, all correlation coefficients are statistically significant with expected sign. For instance, the correlation coefficient between real GDP and the S\&P500 index is very high (0.93) and support the idea that stock prices and GDP are move together. The positive and statistically significant correlation coefficient indicates real GDP and stock prices move in the same direction. We estimate the correlation coefficient between federal spending and the stock prices. Usually, federal spending increases (federal budget deficit widen) during recessions and economic slowdowns in order to restore/support confidence which may help to boost stock prices. Therefore, we expect a negative and statistically significant correlation coefficient between the federal spending and the stock prices. We found negative and statistically significant correlation coefficients between; the S\&P500 index and the net federal budget saving 
(-0.32), the S\&P500 index and cyclically adjusted net federal budget saving (-0.41). The correlation coefficient between real GDP and the federal spending is also statistically significant. The negative and statistically significant correlation coefficient between the S\&P500 index and the fed funds rate (-0.37) may support the idea that during recessions and economic slowdowns the FOMC reduces the rate in order to boost the stock prices. As reduction in the fed funds rate may reduce borrowing cost and increases investments and stock prices. The positive and statistically significant correlation coefficient between the money supply (both nominal and real) and the S\&P500 index may indicates that during economic slowdowns and recessions, normally, the Fed increases money supply and that may helps to restore confidence and support the stock market. The correlation coefficients between real GDP and the fed funds rate as well as real GDP and money supply (both nominal and real) are also statistically significant. Therefore, correlation analysis concludes that the stock prices and real GDP are statistically correlated. Furthermore, fiscal and monetary policies are also correlated with the stock prices and real GDP.

The correlation analysis did support our hypothesis, however, the correlation analysis is too simple to make the final conclusion and we need to do more because the analysis has some limitations. For instance, in correlation analysis we do not specify dependent and independent variables. Furthermore, we need to test for a unit root in order to avoid spurious regression problem.

The next step of our analysis is to test for a unit root. As mentioned earlier that we apply traditional as well as recent/more efficient tests of unit root on all time series. The basic reason behind the unit root testing is that traditional estimation techniques such as OLS assume that time series are stationary. However, if time series are non-stationary and we apply OLS then results may indicate a spurious regression, may lead to a misleading conclusion. In a spurious regression case, usually, we see a very high R-squared and statistically significant t-values with a very low Durbin-Watson d-statistics. (Note 11) In our case, a spurious regression may indicate a statistically significant relationship between confidence/real GDP and monetary/fiscal policy even though, in reality, there is no relationship exit. Therefore, we apply unit root methodology on all series of interest. If all series are stationary at their level form then we can apply OLS and determine whether or not there is a statistically significant relationship exit among confidence, real GDP and monetary/fiscal policy. On the other hand, if all or some series are non-stationary at level form then we have to follow cointegration approach in order to obtain reliable statistical results. We summarize unit root tests results in Table 2. Interestingly, all unit root tests are indicating the same conclusion that is all series, except confidence, are non-stationary at their level form. Furthermore, except confidence, all series are stationary at their first difference. This indicates that if we apply OLS on the series then we may end-up on a spurious regression, a misleading analysis. Therefore, we do not employ OLS for our analysis.

Engle and Granger (1987) proposed that if data series are non-stationary at their level form then we should use cointegration test to get reliable results. Therefore, we apply cointegration tests on the models. Engle-Granger introduced the earliest cointegration test, however, Maddala and Kim (2003) suggested that Engle-Granger cointegration test has lower power. The most popular and commonly use cointegration test in the literature is the one proposed by Johansen (1988). The Johansen's procedure leads to two test statistics for cointegration. The first, called the Trace test, tests the hypothesis that there are at most $r$ cointegrating vectors. The second, called the Maximum Eigen value test, tests the hypothesis that there are $r+1$ cointegrating vectors. Johansen and Juselius (1990) suggested that the Maximum Eigen value test may be a better one. We employ both tests and results are summarized in Table 3, Table 4, and Table 5.

In a simple world, if two variables have a cointegrating vector then that indicates a stable long-run relationship exit between the variables. This implies that if, for instance, confidence and monetary policy are cointegrated then there is a long-run and stable relationship exit between confidence and monetary policy. We run 13 different models in order to test the relationship between (a) confidence and fiscal policy, (b) confidence and monetary policy, and (c) confidence and a combination of monetary and fiscal policies, see Table 3 for results. First, we apply cointegration test on confidence and measures of fiscal policy. We found a cointegrating relationship between confidence and fiscal policy. That indicates a long-run and stable relationship exits between confidence and fiscal policy. Second, we test the relationship between confidence and measures of monetary policy. The results are supporting a long-run relationship between confidence and monetary policy. (Note 12) Finally, we apply cointegration test on confidence and combinations of measures of monetary and fiscal policies. We run six different models which contain six different combinations of measures of monetary and fiscal policies. All models are showing a cointegrating relationship. This implies that a combination of monetary and fiscal policies have a long-run relationship with confidence. In other words, a combination of the policies may have effects on confidence.

Summing up, we found a cointegration in all 13 models. In simple words, a cointegration indicates that a log-run relationship exists between confidence and monetary and fiscal policies. Therefore, confidence, monetary policy, and fiscal policy have a stable and long-run relationship and support our framework. 
We also test the relationship between real GDP and monetary and fiscal policies. Again, we run 13 different models to test the relationship between (a) real GDP and fiscal policy, (b) real GDP and monetary policy, and (c) real GDP and a combination of monetary and fiscal policies, see Table 4 for results. We found evidence of a stable and long-run relationship; series are cointegrated, in all cases. That implies, real GDP and monetary and fiscal polices may have a long-run relationship. In simple words, monetary and fiscal polices may have effects on real GDP.

In a next step, we test long-run relationship between/among; (1) real GDP and confidence, (2) real GDP, confidence and fiscal policy, (3) real GDP, confidence and monetary policy and (4) real GDP, confidence, and fiscal and monetary policies. We run 14 different models to quantify a stable and long-run relationship among the variables, see Table 5 for results. We apply Johansen tests on the GDP and confidence and found that both series are cointegrated. This implies that real GDP and confidence have a stable and long-run relationship. We found same conclusion when we ran cointegration regressions with real GDP, confidence and measures of fiscal policy. Furthermore, the results are supporting a long-run relationship among real GDP, confidence and measures of monetary policy, these variables are cointegrated. We then include real GDP, confidence and both monetary and fiscal polices in the models. The results confirm our thesis that the policies and confidence have a stable, long-run relationship with real GDP. Moreover, fiscal and monetary policies may have effect on both, real GDP and confidence.

We have found a stable and long-run relationship among the variables. The next question would be; is there a short-run relationship exits among real GDP, confidence and monetary and fiscal policies. We follow Vector error correction model (VECM) approach to answer the question. In other words, we extend our analysis and test whether confidence and monetary and fiscal polices have a statistically significant relationship in short-run. We apply VECM on the variables, see Table 6 for results. First, we apply VECM on confidence and measures of fiscal policy and results confirm that measures of fiscal policy have a statistically significant relationship with confidence in the short-run. We also employ VECM on confidence and measures of monetary policy and again found a relationship among the variables. We then include confidence and both policies in the VECM and results are supporting a short-run relationship. We repeat the same procedure for real GDP, fiscal policy and monetary policy, see Table 7 for results. The results indicate a short-run relationship exits among the variables. Finally, we test for a short-run relationship among real GDP, confidence and the policies, see Table 8 for results. The results based on VECM confirm that real GDP, confidence and the policies are associated with each other in short-run. Moreover, confidence and policies may have a correlation with real GDP in short-run.

The conclusion of our statistical analysis is that real GDP, confidence and monetary and fiscal policies are statistically correlated/ associated with each other in long-run as well as in the short-run. Furthermore, monetary and fiscal policies may have effects on confidence as well as on real GDP in the both, short-run and long-run. In addition, real GDP and confidence are statistically correlated/associated in the long-and-short-run.

\section{Concluding Remarks}

The relative effectiveness of monetary and fiscal policies is an on-going debate among macroeconomists. Our study is the first to examine the effect of monetary and fiscal policies on confidence. We provide a theoretical framework which highlights the role of confidence in business cycles as well as the effect of monetary and fiscal policies on confidence. Moreover, we discuss how monetary and fiscal policies restore confidence which leads to the economic recovery from recessions/slowdowns. Furthermore, we test (empirically) the effect of monetary and fiscal policies on confidence as well as on the aggregate economic activities (real GDP).

The conclusion of our statistical analysis is that monetary and fiscal policies have a stable, long-run (as well as short-run) statistically significant relationship with confidence and real GDP. Moreover, real GDP and confidence move together in both the long-run as well as in the short-run. Furthermore, based on our theoretical framework and empirical analysis, we suggest that both policies are important to restore confidence and that may bring in an economic recovery. That being said, in recessions a combination of both policies is necessary to reinstate confidence and boost the economic activities.

\section{References}

Akerlof, G.A. and Shiller, R. (2009). Animal Spirits: How Human Psychology Drives the Economy, and Why It Matters for Global Capitalism. Princeton University Press, New Jersey, USA.

Barro, Robert J. (1997). Macroeconomics. Fifth Edition. The MIT Press, Cambridge, MA.

Bernanke, Ben S. (2010). Monetary Policy and the Housing Bubble. American Economic Association conference. http://www.federalreserve.gov/newsevents/speech/bernanke20100103a.htm 
Dickey, D. and Fuller, W. (1979). Distribution of the estimators for autoregressive time series with a unit root. Journal of the American Statistical Association, 74, 427-431. doi:10.2307/2286348, http://dx.doi.org/10.2307/2286348

Dickey, D. and Fuller, W. (1981). Likelihood Ratio Statistics for Autoregressive Time Series with a Unit Root, Econometrica, 49, 1057-1072. doi:10.2307/1912517, http://dx.doi.org/10.2307/1912517

Elliott, G., Rothenberg, T. J., and James H. (1996). Efficient Tests for an Autoregressive Unit Root. Econometrica, 64:4, 813-836. doi:10.2307/2171846, http://dx.doi.org/10.2307/2171846

Engle, R. and Granger, C. (1987). Co-integration and Error Correction: Representation, Estimation, and Testing. Econometrica, 55, 251-276. doi:10.2307/1913236, http://dx.doi.org/10.2307/1913236

Feldstein, M. S. (2009). Rethinking the Role of Fiscal Policy. American Economic Review, 99, pps 556-59.

Granger, C. and Newbold, P. (1974). Spurious Regressions in Econometrics. Journal of Econometrics, 73 pp. 111-120. doi:10.1016/0304-4076(74)90034-7, http://dx.doi.org/10.1016/0304-4076(74)90034-7

Johansen, S. (1988). Statistical Analysis of Cointegration Vectors. Journal of Economic Dynamics and Control 12, 231-254. doi:10.1016/0165-1889(88)90041-3, http://dx.doi.org/10.1016/0165-1889(88)90041-3

Johansen, S. (1995). Likelihood-Based Inference in Cointegrated Vector Autoregressive Models. Oxford University Press, New York. doi:10.1093/0198774508.001.0001, http://dx.doi.org/10.1093/0198774508.001.0001

Johansen, S. and Juselius, K. (1990). Maximum Likelihood Estimation and Inference on Cointegration- with Applications to the Demand for Money. Oxford Bulletin of Economics and Statistics 52, 169-210. doi:10.1111/j.1468-0084.1990.mp52002003.x, http://dx.doi.org/10.1111/j.1468-0084.1990.mp52002003.x

Keynes, J.M. (1936). The General Theory of Employment, Interest and Money. Palgrave Macmillan.

Krugman, P (2009). The Conscience of a Liberal. Various blogs issues. http://krugman.blogs.nytimes.com/

Kwiatkowski, D., Phillips, P., Schmidt, P. \& Shin, Y. (1992). Testing the null hypothesis of stationarity against the alternative of a unit root: How sure are we that economic time series have a unit root? Journal of Econometrics 54(1-3):159-178. doi:10.1016/0304-4076(92)90104-Y, http://dx.doi.org/10.1016/0304-4076(92)90104-Y

Ludvigson, S.C. (2004). Consumer Confidence and Consumer Spending. Journal of Economic Perspectives, 18, 2 , pages 29-50. doi:10.1257/0895330041371222, http://dx.doi.org/10.1257/0895330041371222

Maddala, G.S. and Kim, I. (2003). Unit Roots, Cointegration, and Structural Change. Cambridge University Press.

Mishkin, F.S. (2009). Is Monetary Policy Effective During Financial Crisis? American Economic Review, 99, pps 573-77.

Nelson, C. R. and Plosser, C. I. (1982). Trend sand random walks in macroeconomics time series: some evidence and implications. Journal of Monetary Economics, 10, 139- 162. doi:10.1016/0304-3932(82)90012-5, http://dx.doi.org/10.1016/0304-3932(82)90012-5

$\mathrm{Ng}$, S. and Perron, P. (2001). Lag length selection and the construction of unit root tests with good size and power. Econometrica, 69, 1519-1554. doi:10.1111/1468-0262.00256, http://dx.doi.org/10.1111/1468-0262.00256

Panagiotis, K and Atthanasios, T. (2010). Boosting Confidence: Is there a Role for Fiscal Policy? Working paper 113, Bank of Greece.

Romer, C. (2009). Lessons from the Great Depression for Economic Recovery in 2009. http://www.brookings.edu/ /media/Files/events/2009/0309_lessons/0309_lessons_romer.pdf

Taylor, John . (2009). The Lack of an Empirical Rationale for a Revival of Discretionary Fiscal Policy. American Economic Review, Vol. 99 no 2. doi:10.1257/aer.99.2.550, http://dx.doi.org/10.1257/aer.99.2.550

Yellen, J.L. (2009). Comments on "the Revival of Fiscal Policy, American Economic Association Conference, San Francisco, CA: http://www.frbsf.org/news/speeches/2009/0104a.html

\section{Notes}

Note 1. Animal Spirits: How Human Psychology Drives the Economy, and Why It Matters for Global Capitalism. Princeton University Press 2009.

Note 2. See the Data section for more detail.

Note 3. See Econometric section for more detail.

Note 4. For more detail see Federal Reserve Board's website: http://www.federalreserve.gov 
Note 5. For more detail see Federal Reserve Board's website: http://www.federalreserve.gov

Note 6. In simple words, crowding out is any reduction in private consumption or investment that occurs because of an increase in government spending (see Barro, 1997 for more detail).

Note 7. TARP allows the U.S. government to purchase or insure up to $\$ 700$ billion of "trouble assts" (assets and liquidity) from financial institutions to strengthen its financial sector (see for more detail: http://www.ustreas.gov/

Note 8. Here we are not explaining these tests in detail because of space limit. See Maddala and Kim (2003) for more detail.

Note 9. It is true that a quantitative measure of confidence (especially willingness factor) is a difficult task and may be our proxy is not the best. But, we do believe that our proxy is better among available options, e.g., TED spread, VIX index (are stay within the financial community and many people hardly heard of them), consumer confidence indices only show consumers' sentiments. Therefore, our measure is broader than the others and covers all major economic agents' sentiments.

Note 10. All results and data are available upon request from authors.

Note 11. As Granger and Newbold (1974) suggested that R-squared > Durbin-Watson d-statistics is a good rule of thumb for a spurious regression.

Note 12. We ran five difference models in order to test the cointegrating relationship between confidence and measures of monetary policy, see Table 3 for more detail.

Table 1. Correlation

\begin{tabular}{|lcc|}
\hline & & \\
\hline Net Federal Budget Saving & -0.52 & -0.32 \\
Cyclically Adjusted Net Federal Budget Saving & -0.59 & -0.41 \\
Federal Funds Target Rate & -0.26 & -0.37 \\
Money Supply (M2, nominal) & 0.98 & 0.91 \\
Money Supply (M2, real) & 0.98 & 0.87 \\
S\&P 500 & 0.93 & 1.00 \\
\hline
\end{tabular}

* All correlation coefficient are statistically significant at $1 \%$.

Table 2. Unit Root Tests

\begin{tabular}{|c|c|c|c|c|c|}
\hline \multirow[b]{2}{*}{ Variables } & \multicolumn{5}{|c|}{ Unit Root Tests } \\
\hline & ADF PP & KPSS & F-GI & ERS & -Perron \\
\hline NFBS & I(1) $\mathrm{I}(1)$ & $\mathrm{I}(1)$ & $\mathrm{I}(1)$ & $\mathrm{I}(1)$ & $\mathrm{I}(1)$ \\
\hline CANFBS & $\mathrm{I}(1) \mathrm{I}(1)$ & $\mathrm{I}(1)$ & $\mathrm{I}(1)$ & $\mathrm{I}(1)$ & $\mathrm{I}(1)$ \\
\hline rn & I(1) $\mathrm{I}(1)$ & $\mathrm{I}(1)$ & $\mathrm{I}(1)$ & $\mathrm{I}(1)$ & $\mathrm{I}(1)$ \\
\hline M2n & $\mathrm{I}(1) \mathrm{I}(1)$ & $\mathrm{I}(1)$ & $\mathrm{I}(1)$ & $\mathrm{I}(1)$ & $\mathrm{I}(1)$ \\
\hline M2r & $\mathrm{I}(1) \mathrm{I}(1)$ & $\mathrm{I}(1)$ & $\mathrm{I}(1)$ & $\mathrm{I}(1)$ & $\mathrm{I}(1)$ \\
\hline Real GDP & I(1) I(1) & $\mathrm{I}(1)$ & $\mathrm{I}(1)$ & $\mathrm{I}(1)$ & $\mathrm{I}(1)$ \\
\hline Confidence & $\mathrm{I}(0) \mathrm{I}(0)$ & $\mathrm{I}(0)$ & $\mathrm{I}(0)$ & $\mathrm{I}(0)$ & $\mathrm{I}(0)$ \\
\hline
\end{tabular}

Where I (1) means order of integration 1, non-stationary at level. I (0) indicate series is stationary at level.

$\begin{array}{ll}\text { NFBS } & =\text { Net Federal Budget Saving } \\ \text { CANFBS } & =\text { Cyclically Adjusted Net Federal Budget Saving } \\ \text { rn } & =\text { Short Term Interest Rate } \\ \text { M2n } & =\text { Money Supply (M2, nominal) } \\ \text { M2r } & =\text { Money Supply (M2, real) }\end{array}$


Table 3. Cointegration Test: Monetary Policy, Fiscal Policy, and Confidence

\begin{tabular}{|c|c|c|c|}
\hline \multirow[t]{2}{*}{ Policies and Confidence } & \multirow[t]{2}{*}{ Variables } & \multicolumn{2}{|c|}{ Johansen Cointegration Test } \\
\hline & & Trace & Maximum \\
\hline \multirow[t]{2}{*}{ Fiscal Policy and Confidence } & Confidence and NFBS & Rank $=1$ & Rank=1 \\
\hline & Confidence and CANFBS & Rank $=1$ & Rank $=1$ \\
\hline \multirow[t]{5}{*}{ Monetary Policy and Confidence } & Confidence and $\mathrm{rn}$ & Rank $=1$ & Rank $=1$ \\
\hline & Confidence and M2n & Rank $=1$ & Rank $=1$ \\
\hline & Confidence and M2r & Rank $=1$ & Rank $=1$ \\
\hline & Confidence, $r n$ and $M 2 n$ & Rank $=2$ & Rank $=2$ \\
\hline & Confidence, $\mathrm{rn}$ and $\mathrm{M} 2 \mathrm{r}$ & Rank $=2$ & Rank $=2$ \\
\hline \multirow{6}{*}{$\begin{array}{l}\text { Monetary Policy, Fiscal Policy and } \\
\text { Confidence }\end{array}$} & Confidence, rn and NFBS & Rank $=2$ & Rank $=2$ \\
\hline & Confidence, $\mathrm{rn}, \mathrm{M} 2 \mathrm{n}$ and NFBS & Rank $=2$ & Rank $=2$ \\
\hline & Confidence, rn, M2r and NFBS & Rank $=2$ & Rank $=2$ \\
\hline & Confidence, rn and CANFBS & Rank $=2$ & Rank $=2$ \\
\hline & Confidence, $\mathrm{rn}, \mathrm{M} 2 \mathrm{n}$ and CANFBS & Rank $=2$ & Rank $=2$ \\
\hline & Confidence, rn, M2r and CANFBS & Rank $=2$ & Rank=2 \\
\hline
\end{tabular}

Table 4. Cointegration Test: Monetary Policy, Fiscal Policy, and GDP

\begin{tabular}{|c|c|c|c|}
\hline \multirow[t]{2}{*}{ Policies and Real GDP } & \multirow[t]{2}{*}{ Variables } & \multicolumn{2}{|c|}{ Johansen Cointegration test } \\
\hline & & Trace & Maximum \\
\hline \multirow[t]{2}{*}{ Fiscal Policy and Real GDP } & Real GDP and NFBS & Rank $=1$ & Rank=1 \\
\hline & Real GDP and CANFBS & Rank $=1$ & Rank $=1$ \\
\hline \multirow[t]{5}{*}{ Monetary Policy and Real GDP } & Real GDP and $\mathrm{rn}$ & Rank $=1$ & Rank $=1$ \\
\hline & Real GDP and M2n & Rank $=1$ & Rank $=1$ \\
\hline & Real GDP and M2r & Rank $=1$ & Rank $=1$ \\
\hline & Real GDP, $r n$ and M2n & Rank $=2$ & Rank $=2$ \\
\hline & Real GDP, rn and M2r & Rank $=1$ & Rank=1 \\
\hline \multirow[t]{6}{*}{ Monetary Policy, Fiscal Policy and Real GDP } & Real GDP, rn and NFBS & Rank $=2$ & Rank=1 \\
\hline & Real GDP, rn, M2n and NFBS & Rank $=2$ & Rank $=2$ \\
\hline & Real GDP, rn, M2r and NFBS & Rank $=2$ & Rank $=1$ \\
\hline & Real GDP, rn and CANFBS & Rank $=2$ & Rank $=2$ \\
\hline & Real GDP, rn, M2n and CANFBS & Rank $=2$ & Rank $=2$ \\
\hline & Real GDP, rn, M2r and CANFBS & Rank $=1$ & Rank $=1$ \\
\hline
\end{tabular}

Table 5. Cointegration Test: Monetary Policy, Fiscal Policy, Confidence and Real GDP

\begin{tabular}{|c|c|c|c|}
\hline \multirow[t]{2}{*}{ The Policies, Confidence and Real GDP } & \multirow[t]{2}{*}{ Variables } & \multicolumn{2}{|c|}{ Johansen Cointegration test } \\
\hline & & Trace & Maximum \\
\hline Real GDP and Confidence & \multirow{7}{*}{$\begin{array}{l}\text { Real GDP and Confidence } \\
\text { Real GDP, confidence and NFBS } \\
\text { Real GDP, confidence and CANFBS } \\
\text { Real GDP, confidence and rn } \\
\text { Real GDP, confidence and M2n } \\
\text { Real GDP, confidence and M2r } \\
\text { Real GDP, confidence, rn and M2n }\end{array}$} & \multirow{3}{*}{$\begin{array}{l}\text { Rank=1 } \\
\text { Rank=1 } \\
\text { Rank=1 }\end{array}$} & \multirow{3}{*}{$\begin{array}{l}\text { Rank=1 } \\
\text { Rank=1 } \\
\text { Rank=1 }\end{array}$} \\
\hline Fiscal Policy, Confidence and Real GDP & & & \\
\hline & & & \\
\hline \multirow{5}{*}{$\begin{array}{l}\text { Monetary Policy, Confidence and Real } \\
\text { GDP }\end{array}$} & & Rank $=1$ & Rank $=1$ \\
\hline & & Rank $=1$ & Rank $=1$ \\
\hline & & Rank $=1$ & Rank $=1$ \\
\hline & & Rank $=2$ & Rank $=2$ \\
\hline & \multirow[t]{2}{*}{ Real GDP, confidence, rn and M2r } & \multirow[t]{2}{*}{ Rank=1 } & \multirow[t]{2}{*}{ Rank $=1$} \\
\hline \multirow{7}{*}{$\begin{array}{l}\text { Monetary Policy, Fiscal Policy, } \\
\text { Confidence and Real GDP }\end{array}$} & & & \\
\hline & Real GDP, confidence, rn and NFBS & Rank $=2$ & Rank $=1$ \\
\hline & Real GDP, confidence, rn, M2n and NFBS & Rank $=2$ & Rank $=2$ \\
\hline & Real GDP, confidence, rn, M2r and NFBS & Rank $=2$ & Rank $=1$ \\
\hline & Real GDP, confidence, rn and CANFBS & Rank $=2$ & Rank $=2$ \\
\hline & Real GDP, confidence, rn, M2n and CANFBS & Rank $=2$ & Rank $=2$ \\
\hline & Real GDP, confidence, rn, M2r and CANFBS & Rank $=1$ & Rank $=1$ \\
\hline
\end{tabular}

Rank=1, Rank=2 and Rank=3 indicate that there are cointegration vector one two and three, respectively. In simple words, if Rank $=1$ (Rank=2 or Rank=3) then there is a long-run relationship exists between (among) the variables 
Table 6. Vector Error Correction Model: Monetary Policy, Fiscal Policy, and Confidence

\begin{tabular}{|l|l|c|}
\hline Policies and Confidence & \multicolumn{1}{|c|}{ Variables } & $\begin{array}{c}\text { Vector Error Correction Model } \\
\text { R-Squared }\end{array}$ \\
\hline Fiscal Policy and Confidence & Confidence and NFBS & 0.29 \\
Confidence and CANFBS & 0.39 \\
Monetary Policy and Confidence & Confidence and rn & 0.39 \\
& Confidence and M2n & 0.36 \\
& Confidence and M2r & 0.39 \\
& Confidence, rn and M2n & 0.42 \\
\hline Monetary Policy, Fiscal Policy and & Confidence, rn and M2r & 0.41 \\
Confidence & Confidence, rn and NFBS & 0.44 \\
& Confidence, rn, M2n and NFBS & 0.48 \\
& Confidence, rn, M2r and NFBS & 0.47 \\
& Confidence, rn and CANFBS & 0.50 \\
& Confidence, rn, M2n and CANFBS & 0.52 \\
\hline
\end{tabular}

Table 7. Vector Error Correction Model: Monetary Policy, Fiscal Policy, and Real GDP

\begin{tabular}{|l|l|c|}
\hline Policies and Real GDP & \multicolumn{1}{|c|}{ Variables } & Vector Error Correction Model \\
\cline { 3 - 3 } & & R-Squared \\
\hline Real GDP and Confidence & Real GDP and Confidence & 0.30 \\
\cline { 1 - 2 } & Real GDP and NFBS & 0.22 \\
& Real GDP and CANFBS & 0.22 \\
\cline { 1 - 1 } Monetary Policy and Real GDP & Real GDP and rn & 0.29 \\
& Real GDP and M2n & 0.22 \\
& Real GDP and M2r & 0.24 \\
& Real GDP, rn and M2n & 0.28 \\
& Real GDP, rn and M2r & 0.30 \\
\cline { 1 - 2 } Monetary Policy, Fiscal Policy and Real GDP & Real GDP, rn and NFBS & 0.35 \\
& Real GDP, rn, M2n and NFBS & 0.34 \\
& Real GDP, rn, M2r and NFBS & 0.36 \\
& Real GDP, rn and CANFBS & 0.34 \\
& Real GDP, rn, M2n and CANFBS & 0.34 \\
& Real GDP, rn, M2r and CANFBS & 0.35 \\
\hline
\end{tabular}

Table 8. Vector Error Correction Model: Monetary Policy, Fiscal Policy, Confidence and Real GDP

\begin{tabular}{|l|l|c|}
\hline Policies and Real GDP & \multicolumn{1}{|c|}{ Variables } & Vector Error Correction Model \\
& & \multicolumn{1}{c|}{ R-Squared } \\
\hline Real GDP and Confidence & Real GDP and Confidence & 0.30 \\
\hline Fiscal Policy, Confidence and Real GDP & Real GDP, Confidence and NFBS & 0.32 \\
& Real GDP, Confidence and CANFBS & 0.31 \\
\cline { 1 - 2 } Monetary Policy, Confidence and Real GDP & Real GDP, Confidence and rn & 0.4 \\
& Real GDP, Confidence and M2n & 0.36 \\
& Real GDP, Confidence and M2r & 0.34 \\
& Real GDP, Confidence, rn and M2n & 0.42 \\
& Real GDP, Confidence, rn and M2r & 0.39 \\
Monetary Policy, Fiscal Policy, Confidence & & \\
& & \\
& Real GDP, Confidence, rn and NFBS & 0.45 \\
& GDP, Confidence, rn, M2n and NFBS & 0.44 \\
& GDP, Confidence, rn, M2r and NFBS & 0.49 \\
& Real GDP, Confidence, rn and CANFBS & 0.5 \\
& GDP, Confidence, rn, M2n and CANFBS & 0.52 \\
\hline
\end{tabular}

In these tables we only report R-squared based on VECM due to space limit. But all results are available on request from the authors. 